Jurnal Iqra' Vol.3. No.1, Januari - Juni 2009

\title{
ETIKA BERKOMUNIKASI GURU DAN PESERTA DIDIK MENURUT AJARAN AGAMA ISLAM
}

\author{
Oleh: Mohamad S Rahman*
}

\begin{abstract}
Abstrak
Etika merupakan hal yang sangat umum, artinya bahwa etika adalah yang mesti diketahui oleh setiap manusia, dalam kehidupan bermasyarakat, namun ketika menjadi prinsip benar dan salah dari perilaku setiap manusia, sedangkan komunikasi dipandang memiliki multi makna dan kompleks, hal ini disebabkan karena komunikasi merupakan suatu fenomena sosial yang dapat diartikaan bermacam-macam (multi makna). Walaupun fenomena komunikasi itu tetap ada dan tidak berubah, namun pemahaman tentang fenomena itulah yang dapat berbeda dari satu orang dengan orang lainnya.

Guru sebagai tenaga pendidik, harus dapat dijadikan contoh dalam beretika dan berkomunikasi. Agar tercapai keberhasilan belajar, maka guru dituntut memberikan pendekatan kepada siswa sesuai dengan keadaan siswa tersebut, disinilah dibutuhkan variasi. Pendekatan dan variasi itu bisa tercapai bila etika dan komunikasi yang digunakan guru sesuai dengan ajaran Islam.
\end{abstract}

Kata Kunci: etika berkomunikasi, guru, peserta didik

\section{Etika dan komunikasi dalam Persepsi}

1. Etika

Dalam buku yang berjudul Etika Komunikasi hasil karya Richard L. Johannessen mengatakan bahwa :

Etika dinyatakan sebagai bagian umum dan sistematis tentang apa yang seharusnya menjadi prinsip benar dan salah perilaku manusia. ${ }^{1}$

Pengertian tersebut menunjukan bahwa etika merupakan hal yang sangat umum, artinya bahwa etika adalah yang mesti diketahui oleh setiap manusia, dalam kehidupan bermasyarakat, namun ketika menjadi prinsip benar dan salah dari perilaku setiap manusia. Oleh karenanya dari individu jelas berbeda, tergantung dari corak kehidupannya. Kehidupan

\footnotetext{
STAIN Manado.

* Penulis adalah dosen tetap pada Jurusan Tarbiyah Program Studi Pendidikan Agama Islam

${ }^{1}$ Ricahrd L. Johannesen, Etika Komunikasi, Bandung: Remaja Rosdakarya, 1996, h. 1.
} 
individu antara satu dengan yang lainnya jelas berbeda, tergantung dari corak kehidupan yang melatar belakanginya. Untuk itu kadang-kadang perilaku individu yang satu dengan yang dianggap salah oleh individu yang lain, terkadang pula bahwa etika yang satu dianggap benar oleh individu lain, sehingga terjadi peniruan perilaku dari individu yang satu kepada individu yang lain.

Dalam pengertian lain, Jonathan Crowther mengemukakan bahwa yang di maksud dengan etika adalah "Of or Relating to moral principles or questions". ${ }^{2}$ Sedangkan J. Coulson mengungkapkan etika adalah "Relating to, treating of, moral or ethics; moral, behaviour". ${ }^{3}$ Dalam pengertian ini antara moral dan etika hampir disamakan, namun kedudukan etika lebih umum dibandingkan dengan moral. Dalam kata lain bahwa etika dipakai untuk ketentuan khalayak umum sedangkan moral dipakai pada ketentuan ketentuan pribadi (akhlak pribadi).

Untuk lebih mendalamnya pengertian etika Penulis juga mengungkapkan pengertian etika yang terdapat dalam Kamus Besar Bahasa Indonesia yakni "Ilmu tentang apa yang buruk dan apa yang baik dan tentang hak dan kewajiban moral (akhlak)". ${ }^{4}$

Dari beberapa pengertian tersebut maka yang dimaksud dengan etika adalah sesuatu yang menjadi prinsip dasar tentang apa yang baik dan apa yang buruk dari perilaku manusia.

\section{Komunikasi}

Dalam kamus Besar Bahasa Indonesia kata komunikasi diartikan sebagai:

Pengiriman dan penerimaan pesan atau berita antara 2 orang atau lebih sehingga pesan yang dimaksud dapat dipahami; hubungan; kontak. ${ }^{5}$

Pengertian tersebut memberikan gambaran bahwa yang dimaksud dengan komunikasi adalah pengiriman atau penerimaan, baik itu pesan maupun berita dari seseorang kepada orang lain dengan tujuan bahwa pesan yang dimaksud dapat dipahami. Dalam hal ini yang dimaksud komunikasi masih dalam konteks komunikasi manusia (orang) bukan termasuk hewan, artinya bahwa komunikasi yang dimaksud di sini hanya mencakup manusia saja, tidak mencakup komunikasi yang terjadi pada hewan.

\footnotetext{
${ }^{2}$ Jonathan Crowther, Oxpord Advanced Pearnes Dictionary, New York: Oxford Univercity Press, 1995, h. 393.

${ }^{3}$ J. Coulson, Oxford Ensiclopedic Dictionary, New York: Oxford Univercity Press, 1991, h. 570.

${ }^{4}$ Departemen Pendidikan dan Kebudayaan RI., Kamus Besar Bahasa Indonesia, Jakarta: Balai Pustaka, 1991, h. 271.

${ }^{5}$ Ibid., h. 517.
} 
Lain halnya arti komunikasi yang dikemukakan oleh Jonatan Crawther, ia mengungkapkan bahwa "Comunication is the action or proses of communicating". ${ }^{6}$ Dalam pengertian ini mencakup berbagai macam bentuk komunikasi yang terdapat pada manusia atau komunikasi yang terjadi antara hewan.

Selain itu, komunikasi yang di maksud dalam pengertian tersebut, hanya sekitar aksi/perilaku dan pross, belum mencakup apa yang harus di pakai dalam berkomunikasi. Untuk itu James G. Robbin mengungkapkan pengertian komunikasi, yang dipandang dari segi apa yang dipakai dalam berkomunikasi, yakni sebagai berikut:

Komunikasi adalah suatu tingkah laku, perbuatan atau kegiatan penyampaian atau pengoperan lambang-lambang, yang mengandung arti atau makna. Atau perbuatau penyampaian suatu gagasan atau informasi dari seseorang kepada orang lain. Atau lebih jelasnya, suatu pemindahan atau penyampaian informasi, mengenai fikiran, dan perasaan-perasaan. ${ }^{7}$

Dari pengertian tersebut jelaslah bahwa komunikasi bisa disampaikan dalam bentuk lambang-lambang yang disampaikan bisa berupa fikiran, gagasan-gagasan, informasi maupun perasaan-perasaan.

Lebih lanjut, Onong Uchjana Efendy dalam bukunya Dinamika komunikasi mengungkapkan bahwa "pengertian komunikasi dibagi menjadi tiga yakni pengertian komunikasi secara etimologi yakni berasal dari kata communis yang berarti sama, dalam arti kata sama makna yaitu sama makna mengenai suatu hal. Yang kedua pengertian komunikasi secara terminologi yakni proses penyampaian suatu pernyataan oleh seseorang kepada orang lain. Sedangkan pengertian komunikasi yang ketiga yakni pengertian komunikasi secara paradigmatis yakni proses penyampaian suatu pernyataan yang dilakukan oleh seseorang kepada orang lain sebagai konsekuensi dari hubungan sosial dan bersifat intensional (mengandung tujuan) misalnya komunikasi melalui surat kabar, radio, televisi atau film. Dan papan pengumuman serta poster". ${ }^{8}$

Dari beberapa pengertian komunikasi yang penulis telah kemukakan memang memiliki multi makna dan kompleks. Hal ini terlihat jelas pada definisi para pakar. Justru itu tidak mungkin bisa dirumuskan suatu definisi yang mencakup semua seginya, sebab komunikasi merupakan suatu fenomena sosial yang dapat diartikaan bermacam-macam (multi makna). Walaupun fenomena komunikasi itu tetap ada dan tidak berubah, namun pemahaman tentang fenomena itulah yang dapat berbeda dari satu orang dengan orang lainnya. Itulah sebabnya tidak mungkin semua pakar bisa sepakat untuk mentapkan satu

${ }^{6}$ Jonathan Crowther, op.cit., h. 230.

${ }^{7}$ James G. Robins, Komunikasi Yang Efektif, Jakarta: Pedoman Ilmu Jaya, 1995, h. 1.

${ }^{8}$ Onong Uchjana Effendi, Dinamika Komunikasi, Bandung: Remaja Rosdakarya, 1993, h. 3-

5. 
fenomna utama dari komunikasi dan memiliki satu rumusan atau definisi yang bisa diterima oleh semua orang. Namun untuk memperoleh pemahaman yang menyeluruh mengenai komunikasi terutama komunikasi yang terjadi pada manusia, semua definisi yang ada berbeda-beda itu, penulis dapat menarik suatu kesimpulan tentang pengertian komunikasi yakni proses penyampaian suatu pesan atau lambang-lambang yang bermakna oleh seseorang kepada orang lain untuk memberi tahu atau untuk mengubah sikap, pendapat, perilaku baik langsung secara lisan maupun tidak langsung melalui media yakni televisi, radio, film, poster, koran dan lain sebagainya.

\section{Etika Guru Terhadap Peserta didik}

Guru merupakan tenaga pendidik yang memberikan ilmu pengetahuan kepada anak dididik di sekolah. Guru haruslah orang yang berpengalaman dalam bidang profesinya sesuai ilmu yang dimiliki. Dengan keilmuannya, dia dapat menjadikan anak didik menjadi orang yang cerdas.

Setiap guru mempunyai kepribadian masing-masing sesuai dengan latar belakang kehidupan sebelum mereka menjadi guru. Kepribadian guru diakui sebagi aspek yang tidak bisa dikesampingkan dari kerangka keberhasilan belajar mengajar untuk menghantarkan anak didik menjadi orang yang berilmu pengetahuan dan berkepribadian. Dari kepribadian itulah mempengaruhi pola kepemimpinan yang guru perlihatkan ketika melaksanakan tugas mengajar di kelas.

Pandangan guru terhadap anak didik akan mempengaruhi kegiatan mengajar guru di kelas. Guru yang memandang anak sebagai individual dengan segala perbedaan dan persamaannya, akan berbeda dengan guru yang memandang anak didik sebagai makhluk sosial. Perbedaan pandangan dalam memandang anak didik ini akan melahirkan pendekatan yang berbeda pula. Tentu saja, hasil proses belajar mengajarnya pun berlainan.

Fenomena tersebut merupakan aspek-aspek yang ikut mempengaruhi keberhasilan belajar mengajar. Paling tidak keberhasilan belajar mengajar yang dihasilkan bervariasi. Kevariasian ini dilihat dari tingkat keberhasilan anak didik menguasai bahan pelajaran yang diberikan oleh guru dalam setiap kali pertemuan. Selain aspek-aspek tersebut, tingkat keberhasilan belajar mengajar terhadap peserta didik. Etika yang baik akan memungkinkan tingkat keberhasilan lebih tinggi dibandingkan dengan etika guru yang kurang baik dalam mengajarnya. Adapun guru yang baik menurut I. L. Pasaribu dalam bukunya yang berjudul Proses Belajar Mengajar adalah guru yang mempunyai sifat sebagai berikut:

1. Menganut dan mendarah dagingkan falsafah Negara Pancasila. Tindakan kita seharihari harus merupakan pemancaran Pancasila, seorang Pancasilais memiliki sifat antar lain banyak berkorban, pengendalian

2. Mengenal dan menggunakan prinsip didaktik dalam setiap mengajar. Alangkah janggalnya seorang yang mengajar tak mengetahui dan tak menjauhkan prinsip didaktik. 
3. memahami situasi serta menghormati murid sebagai subyek. Karena itu guru hendaknya menjauhkan diri dari otoriter.

4. menghormati bahan pelajaran yang di berikan. Orang yang demikian harus menguasai bahan serta mengetahui manfaatnya.

5. Dapat menyesuaikan metode mengajar dengan bahan pelajaran. Adalah ...

6. Memperhatikan perbedaan individu. Tiap-tiap anak mempunyai perbedaan dan kesanggupan dalam mengolah pelajaran. Oleh ...

7. ... Berusaha mengembangkan semua aspek kepribadian (emosional, estetik,etika, intelek), sehingga anak yang bersangkutan dapat bekerja sama dengan orang lain.

8. Memiliki mental health; pekerjaan mengajar harus dilandasi kesehatan mental yang baik, karena guru berusaha mendewasakan murid.

9. Memiliki persiapan; sebelum mengajar harus merumuskan serta memperiapkan pelajaran; a) menentukan dan merumuskan tujuan dari pada pengalaman belajar itu sendiri; b) menyusun suatu rencana strategi pengajaran; c) menyusun rencana untuk menilai efktivitas dari pada rencana strategi pengajaran. ${ }^{9}$

Dari keterangan tersebut menunjukan bahwa seorang guru yang baik haruslah memiliki sifat-sifat tersebut. Agar dalam setiap kegiatan mengajar dan mendidik dapat berhasil dengan seoptimal mungkin.

Selain hal tersebut, guru haruslah memiliki etika dalam menghadapi peserta didik, etika yang dimaksud adalah sebagai berikut: guru haruslah memiliki rasa humor, adil, menarik, lebih demokratis dari pada otokratis, dan mereka harus mampu berhubungan dengan mudah dan wajar dengan peserta didik baik secara individu maupun secara kelompok. Ruang kelas harus dijadikan seperti suatu perusahan kecil dengan pengertian bahwa mereka lebih terbuka, spontanitas, dan mampu menyesuaikan diri kepada perubahan. Sedangkan, guru yang memiliki etika yang kurang baik seperti kurang memiliki rasa humor, mudah menjadi tidak sabar, menggunakan komentar-komentar yang melukai dan mengurangi rasa ego, kurang terintegrasi, cenderung bertindak agak otoriter, dan biasanya kurang peka terhadap kebutuhan-kebutuhan peserta didik. ${ }^{10}$

Dari keterangan-keterangan tersebut telah jelas bahwa, ada dua etika seorang guru yakni etika yang baik berupa memiliki rasa humor, adil, menarik, lebih demokratis dan etika yang kurang baik seperti pemarah, menggunakan komentar-komentar yang melukai perasaan peserta didik.

Hal itu juga telah di pertegas oleh Piet A. Sahertian, beliau mengatakan ada dua macam perilaku yang baik dan perilaku yang kurang baik. Perilaku yang kurang baik meliputi:

a. Melamun, bermalas-malasan

b. Suka melamun menganggur

${ }^{9}$ I.L. Pasaribu, Proses Belajar Mengajar, Bandung: Tarsito, 1982, h. 73-74.

${ }^{10}$ Wasty Soemanto, Psikologi Pendidikan, Jakarta: Rineka Cipta, 1990, h. 220. 
c. Sering meninggalkan tugas

d. Sering absen

e. Selalu cekcok dengan orang lain

f. Apatis terhadap tugas

g. Selalu datang terlambat. ${ }^{11}$

Sedangkan perilaku yang baik meliputi :
a. Penuh kegembiraan
b. Ketetapan hati
c. Antusiasme
d. Rasa senasib sepenanggungan
e. Ingin bekerja sama
f. Selalu mengambil inisiatif. ${ }^{12}$

Untuk itulah seorang guru sebaiknya mengetahui dan mengamalkan etika yang baik. Sebab pada dasarnya seorang guru adalah pemimpin atas dirinya dan peserta didik yang diajarkannya. Hal ini sebagaimana Hadis Rasulullah yang berbunyi sebagai berikut:

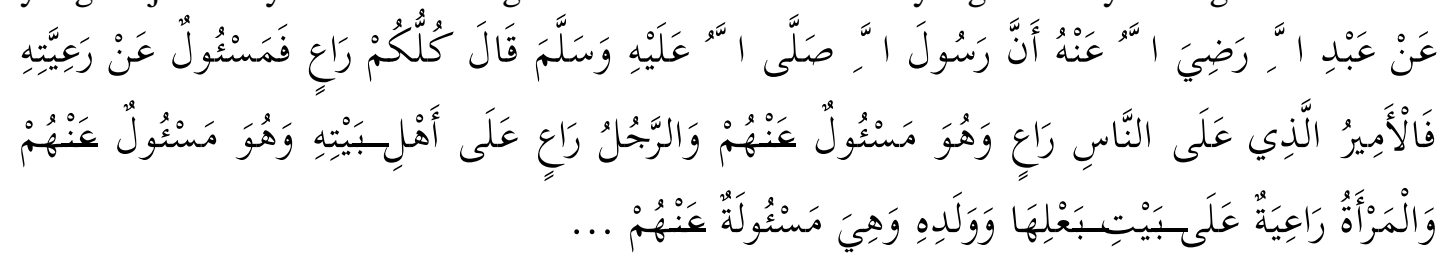

Artinya:

Dari Abdillah ra. Sesungguhnya Rasulullah saw. Bersabda: Setiap kamu adalah pemimpin, dan akan dimintai pertanggung jawaban oleh Allah dalam pimpinan kamu. Seorang suami adalah pemimpin di dalam keluarganya, dan akan dimintai pertanggung jawaban dalam pimpinannya. Seorang isteri adalah pimpinan dalam rumah tangga suaminya dan akan dimintai pertanggung jawaban dalam pimpinannya itu. ( HR. bukhari dan Muslim dari Abdullah bin Umar ). ${ }^{13}$

Dari penjelasan Hadis tersebut tergambar bahwa seorang guru adalah pemimpin baik bagi dirinya sendiri maupun bagi peserta didik yang dididiknya. Olehnya itu seorang guru harus mempunyai etika yang baik. Dalam Islam seorang guru haruslah menjadi seorang yang tidak suka marah (Pemaaf) dan haruslah menyuruh mengerjakan yang ma'ruf, sebagaimana firman Allah yang tercantum dalam QS. Al-A'raaf (7): 199, yang berbunyi: 1981, h. 276.

${ }^{11}$ Piet A. Sahertian, Prinsip dan Tehnik Supervisi Pendidikan, Surabaya: Usaha Nasional,

${ }^{12}$ Ibid.,

${ }^{13}$ Imam Bukhary, Shahih Bukhary, Juz IV, Beirut: Darul Fikri, 1995, h. 233. 


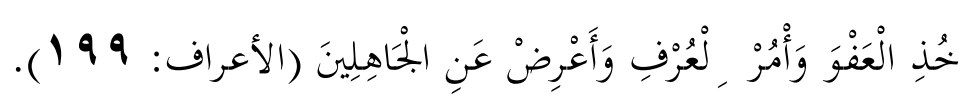

Terjemahnya:

Jadilah engkau pema`af dan suruhlah orang mengerjakan yang ma`ruf, serta berpalinglah daripada orang-orang yang bodoh. ${ }^{14}$

Oleh sebab itu seorang guru haruslah menjadi seorang pema'af dan jika menyuruh kepada peserta didik haruslah yang ma'ruf seperti menyuruh untuk bersabar dan untuk berkasih sayang. Menyayangi sesama teman, makhluk Allah lainnya seperti hewan dan tumbuh-tumbuhan, menghormati guru dan orang tua, menyayangi sanak famili, keluarga dan handai toulan. Hal ini telah dianjurkan oleh Allah dalam firmannya QS. Al-Balad (90): 117 , yang berbunyi sebagai berikut:

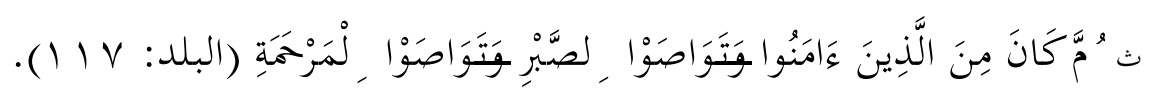

Terjemahnya:

Dan dia termasuk orang-orang yang beriman dan saling berpesan untuk bersabar dan saling berpesan untuk berkasih sayang. ${ }^{15}$

Dari keterangan-keterangan tersebut dapatlah disimpulkan bahwa etika seorang guru terhadap peserta didik adalah tidak mudah marah (menjadi guru yang suka memberi maaf terhadap peserta didik), memberi pesan yang ma'ruf (berpesan untuk bersabar dan berkasih sayang), memberi contoh yang baik (seperti penuh kegembiraan, bekerja sama dan antusiasme), bersikap adil (tidak membedakan antara peserta didik yang satu dengan yang lainnya) dan memiliki rasa humor serta menjunjung tinggi demokratis.

\section{Etika Peserta Didik Terhadap Guru}

Peserta didik adalah orang yang dengan sengaja pergi ke sekolah (lembaga pendididkan) untuk menuntut ilmu pengetahuan. Orang tualah yang memasukan dan menganjurkannya untuk dididik menjadi orang yang berilmu pengetahuan dikemudian hari. Kepercayaan orang tua peserta didik diterima oleh guru dan peserta didik diterima oleh guru dengan kesadaran dan penuh keikhlasan serta tanggung jawab yang besar. Maka terjadilah guru sebagai pengemban tanggung jawab tersebut. Dari hal tersebut terjadilah interaksi antara guru dan peserta didik yang sering disebut dengan proses belajar mengajar.

Tanggung jawab guru tersebut tidak hanya terhadap seorang peserta didik, melainkan dalam jumlah yang cukup banyak dari latar belakang kehidupan sosial keluarga

255.

${ }^{14}$ Departemen Agama RI., Al-Qur'an dan Terjemahnya, Semarang: Toha Putra, 1989, h.

${ }^{15}$ Ibid., 1062. 
yang berlainan. Karenanya, terdapat karakteristik dan etika yang bermacam-macam. Namun dalam pembahasan berikut penulis akan memaparkan etika sebagai peserta didik secara umum.

Menurut Kurt Singer dalam bukunya yang berjudul Membina Hasrat Belajar Disekolah adalah sebagai berikut:

Ilmu pengetahuan ini juga meneliti faktor guru dengan konflik-konflik psikisnya. Apakah yang dirasakan guru tersebut jika ia dengan roman yang dingin, dengan pandangan yang mengejek, dengan senyuman yang penuh dengan penghinaan, atau dengan gerakan tangan yang menyatakan bahwa hal ini tidak ada artinya. ${ }^{16}$

Dari keterangan tersebut tergambar bahwa etika peserta didik dengan muka yang dingin, pandangan yang mengejek serta dengan senyuman yang mengandung penghinaan tersebut merupakan etika peserta didik yang kurang baik. Hal ini dapat mempengaruhi kesenjangan dan ketidak akraban antara peserta didik dan guru sehingga akan menimbulkan proses belajar mengajar terganggu yang pada akhirnya hasil yang didapat kurang memuaskan. Hal ini terjadi karena apabila seorang peserta didik tidak menyukai seorang guru maka secara otomatis materi pelajaran yang dibawakan guru tersebut juga tidak disukainya yang berbuntut peserta didik tersebut enggan untuk mempelajari mata pelajaran tersebut atau sukar dididik, selalu membantah terhadap guru dan selalu melakukan hal-hal yang kurang baik.

Fenomena tersebut sering terjadi dan sering dibicarakan dalam rapat guru-guru, dalam pembicaraan antara guru dan orang tua peserta didik dapat dilihat di majalah-majalah. Sebagaimana ungkapan berikut ini :

Masalah murid-murid yang sukar dididik telah sering dibicarakan dalam rapat guru, dalam pembicaraan antara guru dan orang tua murid, di majalah-majalah dan surat kabar, dan dalam rapat serta pertemuan bertemakan paedagogik. Murid-murid yang sukar dididik ini membawa berbagai masalah bagi guru; oleh karena itu di perlukan masukan-masukan untuk merumuskan suatu cara penanganan atau untuk menjauhkan mereka. ${ }^{17}$

Masalah peserta didik yang sukar untuk dididik ini akan berdampak negatif baik bagi peserta didik yang bersangkutan maupun bagi guru yang mendidiknya bahkan bagi orang tua dan sekolah. Untuk itu dalam Islam dijelaskan bahwa bagi seorang peserta didik dilarang untuk durhaka dalam arti bahwa seorang peserta didik dilarang untuk membangkang, apalagi mencemooh dan meremehkan seorang guru. Sebab durhaka sangat

3.

${ }^{16}$ Kurt Singer, Membina Hasrat Belajar di Sekolah, Bandung: Remaja Rosdakarya, 1987, h.

${ }^{17}$ Ibid., h. 114. 
dibenci oleh Allah sebagaimana firmannya dalam QS. Al-Infithaar (82): 14 yang berbunyi sebagai berikut:

$$
\text { وَإِنَّ الْفُجَّرَ لَفِي جَحِيمٍ (الأنفطار: F أ). }
$$

Terjemahnya:

dan sesungguhnya orang-orang yang durhaka benar-benar berada dalam neraka. ${ }^{18}$

Selain tidak durhaka kepada guru, maka etika yang baik adalah selalu memegang dan mengamalkan amanat-amanat yang baik yang disampaikan oleh seorang guru. Hal ini juga dianjurkan oleh Allah yang tercantum dalam firmannya QS. Al-Anfaal (8): 27, yang bebunyi sebagai berikut:

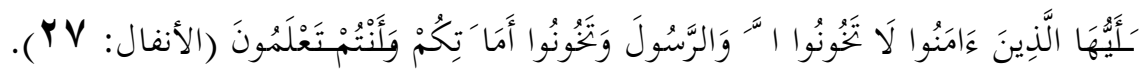

Terjemahnya:

Hai orang-orang yang beriman, janganlah kamu mengkhianati Allah dan Rasul (Muhammad) dan (juga) janganlah kamu mengkhianati amanat-amanat yang dipercayakan kepadamu, sedang kamu mengetahui. ${ }^{19}$

Dari keterangan ayat tersebut telah jelas bahwa menhianati amanat-amanat yang dipercayakan kepada kita sama halnya dengan mengkhianati Allah dan Rasul, karena ketigatiganya sama-sama dilarang.

Dari uraian-uraian yang penulis telah dipaparkan dapatlah disimpulkan bahwa etika yang kurang baik yang dilakukan oleh peserta didik yakni; bersikap dingin terhadap guru, mempunyai pandangan yang seakan-akan mengejek seorang guru, dengan senyumansenyuman yang menunjukan penghinaan serta dengan gerakan-gerakan tangan atau badan yang menyatakan bahwa hal ini tidak ada artinya dan saat guru sedang menerangkan. Sedangkan etika yang baik dan harus dikerjakan dan diamalkan oleh peserta didik yakni tidak mendurhakai seorang guru adalah pendidik dan pengajar, yang patut dihormati dan dihargai; memegang teguh amanat yang di berikan oleh seorang guru dan tidak menghianatinya.

Tatakrama Berkomunikasi Guru Dan Peserta Didik Menurut Islam

\footnotetext{
${ }^{18}$ Departemen Agama RI., op.cit., h. 1033.
}

${ }^{19}$ Ibid., h. 264. 
Seperti diketahui bahwa lapangan pendidikan di mana pekerjaan mendidik berlangsung dalam masyarakat modern ini tidak hanya di keluarga tetapi di sekolah pun pendidikan dapat dilaksanakan oleh guru-guru yang bersangkutan. Sekolah bahkan dipandang sebagi sistem pendidikan normal artinya diselenggarakan atas dasar peraturan dan syarat-syarat tertentu. Tujuan serta alat-alat tertentu pula. Di dalam kelas terjadilah suatu komunikasi yang bersifat paedagogis antara guru dan peserta didik. Dengan adanya komunikasi tersebut terwujudlah proses belajar dan mengajar yang diarahkan dalam ruang lingkup tujuan instruktruksional yang hendak dicapai. Tentunya dalam berkomunikasi tersebut diperlukan etika dan cara-cara berkomunikasi yang baik, agar terjadi interaksi yang harmonis antara guru dan peserta didik.

Etika berkomunikasi yang dimaksud telah diajar oleh Islam yang tertuang dalam ayat-ayat Alqur'an seperti yang termaktub dalam surat an-Nisaa (4): 148 yang berbunyi sebagai berikut:

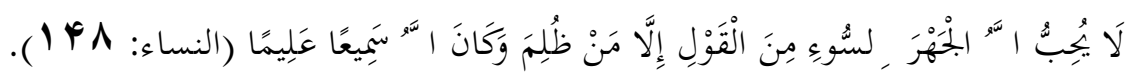

Terjemahnya:

Allah tidak menyukai ucapan buruk, (yang diucapkan) dengan terang kecuali oleh orang yang dianiaya. Allah adalah Maha Mendengar lagi Maha Mengetahui. ${ }^{20}$

Dari penjelasan ayat tersebut tergambar bahwa, baik seorang guru maupun peserta didik dilarang untuk mengucapkan kata-kaya atau ucapan yang buruk. Kata-kata dan ucapan-ucapan yang buruk akan mengakibatkan keengganan antara peserta didik dan guru.

Hal ini disebabkan karena kata-kata dan ucapan ucapan yang buruk (kurang baik) akan menimbulkan kesalahpahaman dan perselisihan diantara mereka dan juga akan mengakibatkan ketersinggungan antara keduanya, yang pada akhirnya proses belajar mengajar akan mengalami hambatan. berikut:

Dalam ayat lain Allah berfirman QS. Al-Isra (17) ayat 53, yang berbunyi sebagai

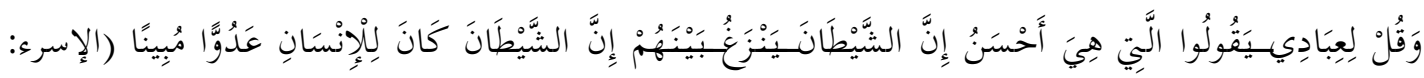

Terjemahnya:

${ }^{20} I b i d .$, h. 147. 
Dan katakanlah kepada hamba-hamba-Ku: Hendaklah mereka mengucapkan perkataan yang lebih baik (benar). Sesungguhnya syaitan itu menimbulkan perselisihan diantara mereka. Sesungguhnya syaitan itu adalah musuh yang nyata bagi manusia. ${ }^{21}$

Perselisihan dan kesalahpahaman adalah hal yang kurang baik, apabila terjadi antara guru dan peserta didik. Bila perselisihan tersebut dibiarkan berlangsung akan mengakibatkan:

1. Kurangnya minat belajar peserta didik dalam proses belajar mengajar terutama terhadap mata pelajaran yang dibawakan oleh guru tersebut.

2. Terjadinya penghinaaan, cemoohan terhadap guru yang bersangkutan meskipun tidak secara terang-terangan.

3. Terjadinya keengganan mengajar bagi guru, karena memandang peserta didik sebagi orang yang tidak perlu dibina, dididik dan diajar.

Selain larangan untuk mengucapkan kata-kata dan ucapan-ucapan yang buruk, dalam Islam juga dilarang untuk memanggil dengan gelar-gelar yang buruk, terutama bagi guru-guru yang memang gemar memanggil peserta didik dengan nama-nama samaran (bukan nama aslinya, hal ini telah dijelaskan oleh Allah dalam firman-Nya QS. Al-Hujuraat (49): 11, yang berbunyi sebagi berikut:

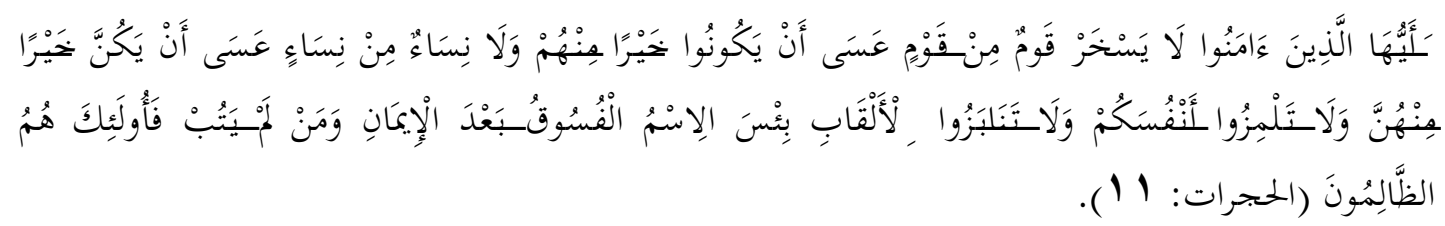

Terjemahnya:

Hai orang-orang yang beriman janganlah suatu kaum mengolok-olok kaum yang lain (karena) boleh jadi mereka (yang diolok-olok) lebih baik dari mereka (yang mengolok-olok) dan jangan pula wanita-wanita (mengolok-olok) wanita-wanita lain (karena) boleh jadi wanita-wanita (yang diperolok-olokkan) lebih baik dari wanita (yang mengolok-olok) dan janganlah kamu mencela dirimu sendiri dan janganlah kamu panggil memanggil dengan gelar-gelar yang buruk. Seburuk-buruk panggilan

${ }^{21}$ Ibid., h. 432. 
ialah (panggilan) yang buruk sesudah iman dan barangsiapa yang tidak bertaubat, maka mereka itulah orang-orang yang zalim. ${ }^{22}$

Untuk itu diharapkan kepada guru janganlah sekali-kali memanggil peserta didik dengan sebutan-sebutan yang buruk yang akan membawa ketersinggungan terhadap peserta didik. Apabila hal ini terjadi maka secara otomatis peserta didik menjadi pesimis terhadap mata pelajaran yang dibawakan oleh guru tersebut dan bahkan akan meremehkannya

Selanjutnya etika berkomunikasi yang baik dalam proses belajar mengajar, terutama bagi peserta didik adalah larangan untuk mendahului ucapan guru. Hal ini telah diajarkan oleh Allah dalam firmanNya QS. Al-Qiyaamah (75): 16-19, yang berbunyi sebagai berikut:

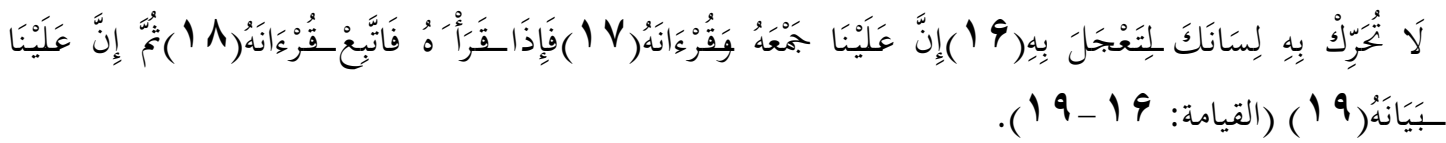

Terjemahnya:

Janganlah kamu gerakkan lidahmu untuk (membaca) Al Qur'an karena hendak cepatcepat (menguasai) nya. Sesungguhnya atas tanggungan Kamilah mengumpulkannya (di dadamu) dan (membuatmu pandai) membacanya. Apabila Kami telah selesai membacakannya maka ikutilah bacaannya itu. Kemudian, sesungguhnya atas tanggungan Kamilah penjelasannya. ${ }^{23}$

Dari keterangan ayat tersebut tergambar bahwa dalam proses belajar mengajar, peserta didik diharapkan untuk mendengarkan lebih dahulu penjelasan, uraian dan keterangan dari seorang guru. Setelah mendengarkan, mengamati, menguasai, merasakan dan memikirkan penjelasan dan keterangan tersebut, barulah dapat berkomentar tentang halhal yang sekiranya belum dimengerti dan dapat pula ditanyakan langsung kepada guru yang bersangkutan dan gurulah yang wajib menjelaskannya.

Biasanya dalam menjelaskan mata pelajaran terhadap anak didik yang mempunyai etika kurang baik, misalnya gaduh, ribut dan mengganggu peserta didik lainnya, maka guru harus mampu untuk menegur dengan baik, lemah lembut dan tidak berlaku kasar, sebab apabila seorang pesera didik dikasarinya maka mereka akan menjauhkan diri. Hal ini telah disinyalir dalam Alquran surat ali-Imran (3): 159 yang berbunyi sebagai berikut:

${ }^{22}$ Ibid., h. 847.

${ }^{23}$ Ibid., h. 999. 


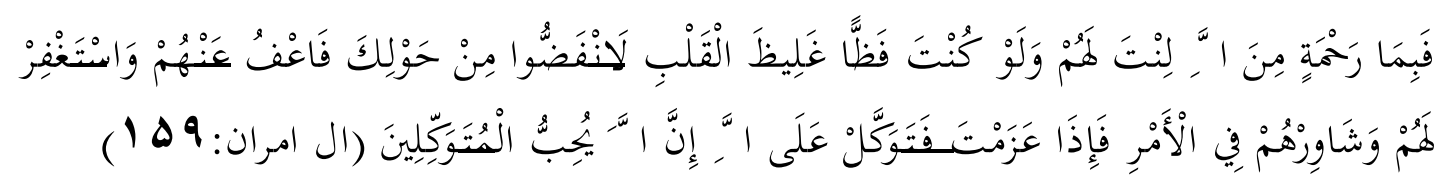

Terjemahnya:

Maka disebabkan rahmat dari Allah-lah kamu berlaku lemah-lembut terhadap mereka. Sekiranya kamu bersikap keras lagi berhati kasar, tentulah mereka menjauhkan diri dari sekelilingmu. Karena itu ma`afkanlah mereka, mohonkanlah ampun bagi mereka, dan bermusyawaratlah dengan mereka dalam urusan itu. Kemudian apabila kamu telah membulatkan tekad, maka bertawakkallah kepada Allah. Sesungguhnya Allah menyukai orang-orang yang bertawakkal kepada-Nya. ${ }^{24}$

Ayat tersebut mengisyaratkan kepada kita khususnya kepada guru agar selalu mengutamakan musyawarah dalam segala urusan terutama dalam menghadapi peserta didik yang nakal.

Dari keterangan-keterangan tersebut yang penulis telah paparkan, dapatlah disimpulkan bahwa etika berkomunikasi antara guru dan peserta didik dalam proses belajar mengajar adalah menggunakan kalimat-kalimat yang baik dan benar, mengutamakan musyawarah dalam mengahadapi kesulitan. Bagi guru sebaiknya tidak menggunakan panggilan-panggilan yang buruk terhadap peserta yang buruk terhadap peserta didik. Dan bagi peserta didik sebaiknya mendengarkan dahulu penjelasan-penjelasan dari seorang guru, bila kurang dimengerti barulah bertanya kepada guru, dengan menggunakan ucapan-ucapan yang baik dan sopan.

\section{Kesimpulan}

Sebagai kesimpulan dari keseluruhan rangkaian pembahasan yang telah dikemukakan yaitu sebagai berikut:

1. Bahwa dalam proses belajar mengajar seorang guru haruslah memiliki rasa humor, adil, menarik dan lebih demokratis serta menjadi seorang yang pema'af. Seyogyanya menyuruh kepada yang ma'ruf seperti menyuruh untuk bersabar dan untuk berkasih sayang terhadap sesama.

2. Bahwa dalam ajaran Islam tidak diperkenankan menggunakan kata-kata atau kalimatkalimat atau ucapan-ucapan yang buruk, karena kata, kalimat atau ucapan yang buruk dapat mengakibatkan perselisihan yang pada akhirnya proses belajar mengajar dapat

${ }^{24}$ Ibid., h. 103. 
terganggu. Sebagai guru juga tidak diperkenankan memanggil peserta didik dengan nama-nama atau gelar-gelar yang buruk (bukan nama sebenarnya) yang dapat membuat ketersinggungan bagi peserta didik. Bagi peserta didik diharapkan jangan mendahului guru dalam berkomunikasi, terutama dalam proses belajar mengajar, karena hal itu dilarang oleh Islam

\section{Daftar Pustaka}

Alquán al-Kariem.

Departemen Agama RI., Al-Qur'an dan Terjemahnya, Semarang: Toha Putra, 1989.

Departemen Pendidikan dan Kebudayaan RI., Kamus Besar Bahasa Indonesia, Jakarta: Balai Pustaka, 1991.

Imam Bukhary, Shahih Bukhary, Juz IV, Beirut: Darul Fikri, 1995.

I.L. Pasaribu, Proses Belajar Mengajar, Bandung: Tarsito, 1982.

James G. Robins, Komunikasi Yang Efektif, Jakarta: Pedoman Ilmu Jaya, 1995.

Jonathan Crowther, Oxpord Advanced Pearnes Dictionary, New York: Oxford Univercity Press, 1995.

J. Coulson, Oxford Ensiclopedic Dictionary, New York: Oxford Univercity Press, 1991.

Kurt Singer, Membina Hasrat Belajar di Sekolah, Bandung: Remaja Rosdakarya, 1987.

Onong Uchjana Effendi, Dinamika Komunikasi, Bandung: Remaja Rosdakarya, 1993.

Piet A. Sahertian, Prinsip dan Tehnik Supervisi Pendidikan, Surabaya: Usaha Nasional, 1981.

Ricahrd L. Johannesen, Etika Komunikasi, Bandung: Remaja Rosdakarya, 1996.

Wasty Soemanto, Psikologi Pendidikan, Jakarta: Rineka Cipta, 1990. 
Jurnal Iqra' Vol.3. No.1, Januari - Juni 2009 